\title{
A digitális kotta mint digitális tananyag
}

A zenepedagógusok új kihívások elótt állnak - elég, ha csak a minósítési rendszerre vagy a tanulók megváltozott tanulási igényeire, zenehallgatási szokásaira gondolunk. A digitális kompetencia már

nem csak lehetóségként, hanem elvárásként jelenik meg a hangszeroktatásban. Áttekintjük, hogyan jutottunk el az elsó otthoni számitógépektól az IKT-eszközökig, a papiralapú kottától a digitális kottatartóig, és megvizsgáljuk, hogyan hathat a technológia fejlódése a hangszeres zenepedagógia módszertani megújulásra. Digitális kotta vs. digitalizált kotta. Honnan szerezze be és hol tárolja zenei

fájljait egy tartalomszolgáltató tanár? Eljutva az interaktív zeneoktató programokig, feltesszük a kérdést: „viszi” ez a lehetôség a tanulót vagy „hozza”? Végül az utolsó szó jogán a szerzói jogi aspektust is áttekintjük.

\section{Intro(duction) $)^{1}$}

A z oktatási reform azon napjait éljük a 2014/2015-ös tanévben, amikor a tervezett változások már szervesülnek a rendszerben, egyebek mellett érintve az intézményirányítást, az adminisztrációt, a tantervet és a tananyagot is. Ezek a változások az alapfokú, középfokú- és felsőfokú müvészetoktatás számos területét is elérték, de más tárgyakkal, szakokkal ellentétben a tanterv és a tananyag szinte teljesen érintetlen maradt. Felmerül a kérdés, hogy miért releváns mégis ez a téma. Annak ellenére, hogy a tanterv és a tananyag valóban nem változott, a pedagógus minősítési rendszer bevezetése és az ahhoz kapcsolódó minősítési eljárás szempontrendszere számos ponton megköveteli a tanár digitális kompetenciáját és annak széleskörü használatát. ${ }^{2}$ Ebben a dokumentumban nem találkozunk a digitális kotta kifejezéssel, azonban a digitális tartalom és eszközök használatára több kompetencia kapcsán is elvárásként utal. A minősítési rendszer elindulása és müködése optimális esetben egy fejlödési spirált fog elindítani, melynek várható eredménye módszertani megújulás lehet.

A tanárok szempontjából ez egy felülről jövő „nyomás”, de van egy másik presszió is. Ez a diákok megváltozott tanulási, ismeretszerzési, zenehallgatási, kommunikációs szokásaiból fakad. Annak ellenére, hogy a számítástechnikai eszközök már mintegy 35 éve jelen vannak az oktatásban, ez a helyzet csak az utóbbi 15 évben élesedett ki. Ennek az az oka, hogy ekkor került be az iskolai oktatás rendszerébe az ún. Z generáció. Ezek azok a gyermekek, akik 1995 és 2009 között jöttek világra, és akik már beleszülettek ebbe a digitalizált térbe (McCrindle Research, 2014). Ök már ügyesebben kezelik a táblagépet vagy az érintőképernyős mobiltelefont, mint a televízió távirányítóját. Jó példa erre saját 1,5 éves gyermekem, aki a televízió képernyőjét úgy próbálta interaktivitásra bírni (lapozva akart képernyőt váltani), mintha egy táblagép képernyője lenne. Számukra 
bármilyen technikai eszköz használata ugyanolyan kihívás, mint a járás vagy a beszéd elsajátítása. Az érintőképernyő - interaktivitása miatt - a mindenre nyitott gyermek számára egy felfedezésre váró világ, képes-hangos játék, ami reagál az érintésére, de akár a felhasználó hangjára vagy szemmozgására is. A gyermekek explorációs területe kitágul, az ismeretszerzés és feldolgozás eszközkészlete bővül. Ha ezt a pedagógusok

Talán nem túlzás kijelenteni, hogy a zenetörténet legnagyobb, „legvéresebb" forradalmát a digitális technológia megjelenése hozta el. Ahogyan az lenni szokott, egy forradalom veszteséggel, áldozatokkal jár, de egyúttal megújulást, fejlōdést, letisztulást is hozhat magával. A digi-

tális forradalom jelentôsen átalakította - és folyamatosan alakitja - a teljes zeneipart, ideértve a szerzók, elóadók, kottaés zenei kiadók, músorszolgáltatók életét és a zeneoktatást is. Altalában a negatív hatásokról hallunk - csökkenó eladási adatokról, illegális letöltésekról, csökkenó koncert-nézószámról és egyre kevesebb zeneiskolai tanulóról, nem beszélve az ének-zene oktatás válságáról -, és csak keveset a pozitívumokról és új lehetôségekról. és a pedagógusképzés figyelmen kívül hagyja, akkor az a hatalmas digitális szakadék, mely már most ott tátong a ma aktív tanárok és a tölük tanulók között, csak tovább fog mélyülni.

A környezetünkben lévő képernyők számának növekedésével párhuzamban - vagy éppen ezért - az olvasással szemben inkább a vizualitás kerül előtérbe. A Z generációról elmondható, hogy inkább megnézi, vagy meghallgatja, mint könyvben elolvassa (lásd hangoskönyvek, interaktív könyvek, könyv applikációk, filmadaptációk megjelenése, elterjedése). Annak eldöntése, hogy a digitális eszközök használta a hétköznapi életben vagy az oktatásban elönyös vagy hátrányos, nagyon nehéz, hiszen ehhez több aspektust is szükséges alaposan megvizsgálni.

Az egyik ilyen területet számos tanulmány már a '80-as évektől kutatja. Arra kerestek választ, hogy az agyunk másképp reagál-e a képernyőről olvasott és a hagyományos papíralapú szöveg értelmezése, feldolgozása esetén. 1992-ben Dillon egy tanulmányban foglalta össze az ebben a témakörben végzett addigi kutatások eredményeit, melyek többek között az olvasás sebességét, pontosságát és megértését mérték. Mindhárom tényező esetében a képernyő-alapú olvasás mutatott rosszabb eredményeket ( $\mathrm{Dil}$ lon, 1992). Ezt látszik alátámasztani az a nemrégiben egy norvég általános iskolások körében végzett kutatás is, mely a szövegértést vizsgálta. Szignifikánsan jobban teljesítettek azok a diákok, akik nem digitálisan, hanem nyomtatott formában olvasták a szöveget (Mangen és mtsai, 2013). A digitális kotta és a papíralapú kotta olvasásának összehasonlítását lényegesen kevesebb kutatás célozta meg ez ideáig, de Picking (1997) is arra az eredményre jutott, hogy a képernyőről olvasott kotta olvasása kevésbé hatékony. A digitális technológia térnyerése azonban ennél sokkal drámaibb hatást gyakorolt a zene teljes spektrumára.

Talán nem túlzás kijelenteni, hogy a zenetörténet legnagyobb, „legvéresebb” forradalmát a digitális technológia megjelenése hozta el. Ahogyan az lenni szokott, egy forradalom veszteséggel, áldozatokkal jár, de egyúttal megújulást, fejlődést, letisztulást is hozhat magával. A digitális forradalom jelentősen átalakította - és folyamatosan alakítja - a teljes zeneipart, ideértve a szerzők, előadók, kotta- és zenei kiadók, müsorszolgáltatók életét és a 
zeneoktatást is. Általában a negatív hatásokról hallunk - csökkenő eladási adatokról, illegális letöltésekről, csökkenő koncert-nézőszámról és egyre kevesebb zeneiskolai tanulóról, nem beszélve az ének-zene oktatás válságáról -, és csak keveset a pozitívumokról és új lehetőségekről. Bizonyos szempontból szét is választhatnánk az üzleti vállalkozások problémáit az oktatás gondjaitól, azonban a transzferhatások miatt mégis érdemes globálisan kezelni a kialakult helyzetet. A rendszer elemei, illetve szereplöi szervesen kapcsolódnak egymáshoz, mivel alá-, fölé- és mellérendeltségi viszonyban állnak egymással.

A krízis megoldásában az oktatásnak kulcsszerepe van, hiszen személyiségformáló ereje a társadalom széles rétegeire hat. Éppen ezért a közoktatásban folyó ének-zene órák eredménytelensége a legaggasztóbb, hiszen ebben minden tanuló részt vesz, aki általános iskolába jár. Az itt folyó munka minősége és hatékonysága kulturális, pedagógiai vonatkozásban és a személyiségfejlesztés szempontjából is meghatározó. Janurik szerint a „tanulók körében rendkívüli mértékben csökkent a klasszikus zene népszerüsége, az énekórák apátiát, unalmat és szorongást váltanak ki a tanulókból" (Janurik, 2007). „A Kodály ének-zenei tanítási koncepció szerint tanuló - nem zenei tagozatos - iskolák tanulói a legkevesebb öröm és a legtöbb apátia, unalom és szorongás kíséretében az iskolai ének-zeneórákat élik át" (Janurik és Petö, 2009).

Ezzel szemben Búzás (2012) IKT-eszközökkel támogatott interaktív énekóráinak tapasztalatait a következőképpen összegzi: „A tanórák anyagait Kodály Zoltán zenepedagógiai koncepciója alapján állítottam össze. Az interaktív énekórai részvételt többek között az alábbi állításokkal igyekeztem megvizsgálni: könnyen fenn tudtam tartani a figyelmet az interaktív órán, lekötöttek a feladatok, belemerültem a munkába, az órán a legtöbb osztálytársam jól dolgozott, könnyedén megoldottam a feladatokat, érdekes volt számomra, ami az órán történt. A vizsgálat eredménye szerint $72 \%$ azoknak a diákoknak az aránya, akik egyetértettek azzal, hogy könnyedén fenn tudták tartani a figyelmüket, illetve könnyedén megoldották a feladatokat (82\%). Ehhez kapcsolódóan magas azoknak az aránya, akik érdekesnek tartották az órán történteket (66\%). A felmérés szerint az interaktív énekóra alatt a szorongó diákok aránya mindössze 6\%, a legtöbben (61\%) jól érezték magukat az órán és nem unatkoztak $(50 \%)$."

\section{Miért fontos a digitális kompetencia a hangszeroktatásban?}

Az előzőekben leírt két felmérés is azt mutatja, hogy a digitális kompetencia megléte és alkalmazása mennyire fontos napjaink pedagógiájában. A digitális kompetenciát azonban nem lehet pusztán iskolában megtanulni, azt folyamatos fejlesztés eredményeként lehet elsajátítani. Ez egyaránt vonatkozik a tanárokra és a tanulókra, de nem jelenti azt, hogy ne lenne szükség számítástechnika órára vagy e-learning kurzusra. A zenepedagógus képzés tekintetében azonban sajnos még az tapasztalható, hogy az IKT-eszközök használatával kapcsolatos tárgyak, kurzusok nincsenek specializálva. Ennek okai a nem-upgrade-elt módszertan és a nem-update-elt oktatói gárda.

Az OECD által szervezett TALIS vizsgálat eredménye alapján ${ }^{3}$ a tanárok 12 százaléka 30 év alatti, 58 százaléka 30 és 49 év közötti és 30 százaléka 50 év feletti, ami azt jelenti, hogy nagy részük digitális bevándorló. Ezek a pedagógusok hiába jól képzettek szakterületükön, és rendelkeznek sokéves tanítási tapasztalattal, ha a digitális kompetencia területén hiányosságokkal bírnak. Ennek okai lehetnek, hogy ezen ismeretek megléte sem a diplomájuk megszerzésének, sem pedig pedagóguspályájuk gyakorlásának eddig nem volt feltétele. Ilyen (tovább)képzésen csak azok vettek részt, akiket ez a téma foglalkoztatott. Komoly dilemma, hogy hogyan lesznek képesek ezek a tanárok az új generáció digitális kompetenciájának megalapozására és a minősítési rendszer követelményeinek való megfelelésre. 
A tanárképzés nagy feladat előtt áll, hiszen a $Z$ generáció tagjai most kerülnek be a felsőoktatás rendszerébe. Nekik már most erre az új kihívásra felkészített oktatók kész módszertani eszközöket kell(ene) a kezükbe adjanak ahhoz, hogy öt év múlva a képzésből kilépve, ebböl a szempontból is jól felvértezve állhassanak a tanári pulpitusra.

Nem szabad elfeledkeznünk a technikai háttér pillanatnyi állapotáról sem. Hiába a képzett oktatói gárda, ha a megvalósítás gátja a forrás- vagy eszközhiány. Ha ma körbejárjuk az ország zeneoktatási intézményeit, akkor szomorúan láthatjuk a technikai felszereltség vagy leromlott állapotát, vagy teljes hiányát.

\section{Tananyagfejlesztés}

A tananyag fejlesztése alatt eddig leginkább az új vagy már meglévő hangszeriskolák javított változatának papíralapú kiadását értettük. A digitális technológia fejlődése azonban lehetővé tette a „platformváltást”, azaz a kottakép átkerülését a papírról a képernyőre. Így lesz a hagyományos (analóg) tananyagból digitális tananyag. Azok a zenetanárok, akik tanulóik számára olyan online elérhető felületet üzemeltetnek vagy biztosítanak, melyen digitális oktatási anyagokat tesznek elérhetővé letöltés és/vagy kollaboratív munka céljából, tartalomszolgáltatókká válnak. Ez a felület lehet egy weboldal, blog vagy felhőalapú szolgáltatás, esetleg saját szerver fenntartása. Egy ilyen rendszer üzemeltetéséhez „haladó” digitális kompetenciára van szükség, azonban már ,alapfokú” ismeretekkel is van lehetőségünk külső források felkutatására, közzétételére.

Az egyik ilyen magyar forrás a www.digitalistananyag.hu. Ott azonban azt tapasztalhatjuk, hogy ugyan az ének-zene oktatáshoz találunk néhány CD-t, illetve DVD-t, de a hangszeroktatáshoz semmilyen anyag nem áll rendelkezésre. Ha külföldi oldalakon böngészünk, már fellelhetünk olyan digitális kottabázisokat, tanulást segítő alkalmazásokat, speciális hardvereket, melyek oktatási céllal készültek. Ezekről később még szólunk.

Véleményem szerint a digitális kotta elterjedésének másik gátja hazánkban - a digitális kompetencia hiánya mellett - a nem pontosan tisztázott jogi háttér és az, hogy az ebből a szempontból fejlettebb nemzetközi gyakorlatban hatályos szerzői jogi törvények csak viszonylag lassan ,szivárognak át”.

Ahhoz, hogy a jelen pillanatban rendelkezésre álló IKT-eszközök pedagógiai célú felhasználásának lehetőségeit vizsgáljuk, érdemes azok fejlődéstörténetét is áttekinteni. Írásom a hőskor általam fontosnak tartott technológiáinak, fejlesztőinek, gyártóinak bemutatásával kezdődik és a napjaink osztálytermében használható legmodernebb zeneoktató szoftverekkel és mobileszközökkel záródig. Több mint három évtized minden, a témával kapcsolatba hozható hardveres és szoftveres fejlesztésére nem fogok kitérni, de megpróbálok olyan fordulópontokat, tendenciákat megragadni, melyek máig hatnak, és pedagógiai vonatkozásaik is fellelhetőek.

\section{A számítástechnika megjelenése az otthonokban és az oktatásban}

Bár az igazi áttörést az 1980-as évek hozta el, az otthoni számítógépek sikertörténete 1977-ben kezdődött három komputer megjelenésével: TRS-80, Commodore PET, Apple II. Ez volt az úgynevezett „1977 Trinity” (Byte Magazine, 1995). A TRS-80 ugyan korának meghatározó személyi számítógépe volt, néhány éves története a cikk témájának szempontjából irreveláns, ezért további bemutatásától most eltekintek.

A másik két gép gyártója azonban - azt hiszem túlzás nélkül állíthatom - több szempontból is történelmet írt. Az Apple Computer (ma Apple Inc.) első sikeres tömeggyártású mikroszámítógépe, az Apple II tekinthető a ma ismert PC-k ősének, ez volt „,az első 
igazi személyi számítógép" (Gröger, 1999). Az oktatási eszközként való felhasználás egyik állomása már 1978-ban elérkezett. 500 db Apple II-t szállítottak minnesotai állami iskolákba, a Minnesota Education Computing Consortium eddigre már összeállított, jelentős oktatási programokat tartalmazó csomagjának támogatásával, mely ingyenesen állt az iskolák rendelkezésére (Waters, 2015). 1979 újabb mérföldkő a cég életében. Létrehozzák az Apple Education Foundationt, mely iskolák számára komplett oktatási szoftverekkel felszerelt Apple számítógépeket biztosít. Ez ismét kitünő döntésnek bizonyul, hiszen az Apple II a diákok egyik legkedveltebb számítógépévé válik, és ez a vállalat következő éveinek fő bevételi forrását biztosítja (Gröger, 1999).

Itt érdemes egy bekezdés erejéig elöre ugrani az időben, egészen 2012-ig. Steve Jobs halála után Bill Schiller, a cég alelnöke ezt nyilatkozta: „Az oktatás mélyen az Apple DNS-ében van” (Watters, 2015). Végigtekintve Steve Jobs életpályáját, ez leginkább az ő szellemiségéből fakadt. Az volt az álma, hogy minden iskolában legalább egy számítógép legyen, mellyel a gyerekek kapcsolatba kerülhetnek. Tudta, hogy ez a találkozás megváltoztatja majd az életüket. Látta a bürokrácia lassúságát, és hogy kimegy az oktatásból egy generációnyi gyermek anélkül, hogy megismerkedne a számítástechnikával. Úgy gondolta, hogy a gyerekek nem tudnak várni („Kids can’t wait”, ez később az iskolák számítógéphez jutását támogató kezdeményezésük neve is lett). Az a terv, hogy az Apple minden iskolának - mindegy százezer intézményről volt szó - adományoz egy számítógépet, szóba sem jöhetett a hatalmas kiadás miatt. A korabeli jogot tanulmányozva találtak egy törvényt, mely szerint azok, akik kutatási eszközt vagy számítógépet adományoznak egyetemnek oktatási célra, adókedvezményt vehetnek igénybe. Azt szerették volna elérni, hogy ezt a törvényt terjesszék ki minden iskolatípusra, és a kutatási támogatás helyett csak az oktatási célú felhasználás legyen a kritérium. Jobs célja elérése érdekében személyesen találkozott politikusokkal, és végül sikeres lobbitevékenysége eredményeként Kalifornia kormányzója 1982 szeptemberében aláírta az AB 3194-es törvényt, mely 25 százalékos társaságiadó-kedvezményben részesítette azokat a cégeket, akik számítógépet adományoztak iskoláknak. A Kids can’t wait program keretében Kalifornia állam 900 iskolája jutott Apple számítógéphez ingyen. Az adomány része volt 25 ingyenes vagy kedvezményes oktatási programhoz való hozzájutás lehetősége, és emellett dealer-hálózatukon keresztül ösztönözték az iskolai személyzet továbbképzését is (Watters, 2015).

A Commodore cég a 1970-es évek elején még a számológépek piacán tevékenykedett, de az évtized közepén végbement alkatrészdrágulás miatt lépéskényszerbe került. Az új irányt a számítógépgyártás jelentette. 1976 szeptemberében Steve Jobs és Steve Wozzniak eladásra kínálta az Apple II prototípusát, amit Jack Tramiel - a cég tulajdonosa - túl drágának talált és visszautasított (Smith, 2012). Tramiel ezután 6 hónapos határidővel megbízást adott Chuck Peddle-nek, Bill Seiler-nek és John Feagans-nek egy új számítógép kifejlesztésére. Ez lett az első all-in-one számítógép: a Commodore PET, mely a céget hamarosan Kanada és az Egyesült Államok oktatási piacának elsőszámú csúcsforgalmazójává tette. A strapabíró fémházba zárt minden-az-egyben 4032-es sorozat tökéletesnek bizonyult a ,zord” osztálytermi körülmények között. A rajta található IEEE-488-as port lehetővé tette egyszerü osztálytermi hálózatok létrehozását és nyomtatók vagy egyéb külső eszközök csatlakoztatását. Ahogy az Apple, úgy a Commodore is nagyon erősen küzdött a minél nagyobb piaci részesedésért, melyre jó példa egyik iskoláknak szánt „kettőt fizet, hármat kap” akciójuk, ahol harmadikként a tanároknak fejlesztett „Teacher's PET”-et adták ajándékba.

Az Apple és az ATARI számítógépeinek grafikai és hangi képességei továbblépésre sarkallták a céget. Válaszuk a VIC-20 volt - 1980-at írunk -, és annak továbbfejlesztése, a Commodore 64. 1983-ban a Commodore árképzésével kirobbantotta az „otthoni számítógépek háborúját" ( $A h l, 1984)$, aminek eredményeként a C64 11 éves pályafutása 
alatt a világon a legnagyobb darabszámban eladott mikroszámítógépeként bekerült a Guinness Rekordok Könyvébe (Griggs, 2011). Az oktatási szegmenset továbbra sem adták fel, hiszen már 1983-ban elkészítették a C64-es alapjain nyugvó PET64-et monokróm monitorral, és az Educator 64-et szürkeskálás monitorral, de a sikernek éppen ez a „visszafogott” grafikai megjelenés szabott gátat.

Az 1980-as évek elképesztő innovativitásának következő bizonyítéka az IBM PC vagy IBM kompatibilis PC-k megjelenése, fejlődése. Hazánkban napjainkig javarészt ennek a „gépcsaládnak” a leszármazottait használjuk, ha az úgynevezett asztali számítógépekre gondolunk. 1980-ban az IBM vezetősége, látva az Apple sikerét a mikroszámítógépek piacán, úgy döntött, hogy ők is kifejlesztenek egy személyi számítógépet. 1981 augusztusában forgalomba került az első IBM PC. Az alapkoncepció az volt, hogy mind szoftveres, mind hardveres szempontból nyitott legyen a rendszer, tehát bárki tudjon rá fejleszteni (Sandler, 1984). A mai napig tartó siker egyik kulcsa éppen a kompatibilitás, de sok bosszúság forrása is lett ez a későbbiekben, hiszen a több ezer gyártó terméke nem mindig müködött együtt tökéletesen. Az új konfiguráció három operációs rendszerrel került forgalomba, de a legolcsóbb és egyben a legsikeresebb az lett, amelyen a Microsoft PC DOS futott. Az IBM ráadásul hozzájárult ahhoz, hogy a Microsoft más IBM PC kompatibilis gépekhez is eladhassa rendszerét (Miller, 2011), mely lehetöség nagymértékben hozzájárult Bill Gates cégének későbbi hatalmas sikeréhez.

A kor hangulatát idéző újságcikk apropóján érdemes még egy gyártóra felhívni a figyelmet, aki később a személyi számítógépeken futó zeneszerkesztő programok elterjedésének úttörője lett. A Montreal Gazett 1982. március 20-án megjelent számában Computers bring 21 st century to five-year-old címmel jelent meg egy cikk, mely arról számol be, hogy egy montreali belvárosi iskolában hogyan ismerkednek a tanulók a számítógépekkel. A Bancroft Elementary School egyike volt az első olyan általános iskolának, ahol a számítógépeket az oktatásban alkalmazták. A cikk beszámol arról, hogy a termekben ATARI 400-as számítógépeken ismerkednek a tanulók a számítógépes parancsokkal egy pilot projekt (milyen aktuális kifejezés!) keretében, mely a számítógépes ismeret, a „computer literate” megszerzését célozza meg a 6-12 éves korosztály számára. A nebulók rajzolnak, kottát készítenek digitálisan, programoznak és szöveget szerkesztenek (Frucht, 1982). A Futerescope címü tévémüsor is beszámolt erről a projektről. ${ }^{4}$

A cikk számos érdekességéböl két részletet szeretnék még kiemelni:

„A számítógépek segítenek a tanulók osztálytermi motiválatlanságán.

Az általános iskolai oktatásban alkalmazható számítógépek elterjedésével kapcsolatban az az egyik probléma, hogy kevés a szakképzett oktató, és a másik, hogy számos tanár soha nem használt még számítógépet, így megtanítani sem tudja annak használatát." (Frucht, 1982)

\section{„Zenélő" gépek - „Gépelő” zenészek}

Talán magyarázatra szorul, miért tettem idézőjelbe a 'zenélő' és 'gépelő' szavakat. Mind a hardverek, mind pedig a szoftverek nagyon frissek voltak, néhol ,gyermekbetegségekkel”, kiforratlanságokkal, zsákutcákkal, még csak korlátozott képességekkel. A zenészek is csak sejtették vagy sejthették a mélyben rejlő lehetőségeket.

Az egyik úttörő zenészröl, Ryo Kawasakiról egy 2003-ban vele készült interjúból a következőket tudhatjuk meg. Az elsők között volt, amikor „talán” 1983-ban 600\$-ért (monitor nélkül) megvásárolt egy C64-es számítógépet. 1978 és 1982 között saját gitárszintetizátort fejlesztett, melynek müködési elve közel állt a SID chip (mely a Commodore megszólalását biztosította) hangparaméterezési tulajdonságaihoz. Az új számítógép adta lehetőségek annyira inspirálták őt, hogy kevesebb mint hat hónap alatt megtanulta a BASIC és a gépi kód nyelvet. „2-3 éven át napi 16 órát programoztam” - emlékszik 
vissza a zenész-programozó. Ennek az elképesztő mennyiségű munkának az eredménye négy zenei szoftvere: a Kawasaki Synthesizer, a Kawasaki Rhythm Rocker, a Kawasaki Magical Musicquill és a Kawasaki MIDI Workstation (Raf/Samar, 2003). A Kawasaki Synthesizer (1. ábra) már egy igazi zeneoktató program volt. A „szerzö-programozó” végigvezette a felhasználót a program bemutatásától (Demo), a zeneszerzéshez szükséges kezdeti lépéseken át (Easy Beginner Version) az önálló zeneszerzésig (Performer), ahol a müvek el is voltak menthetőek. Ez az interaktív zeneoktató program a számítógép billentyüzetét szintetizátorrá alakította.

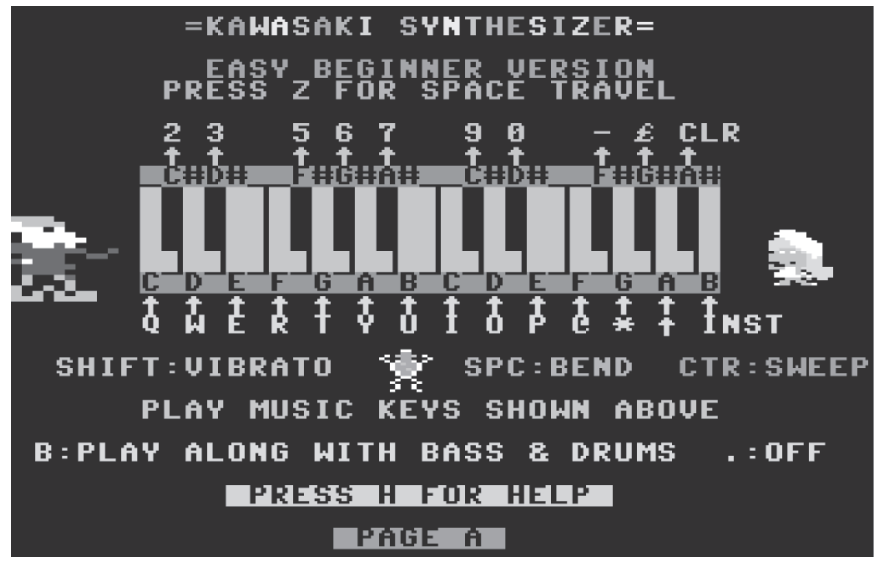

1. ábra. A Kawasaki Synthesizer program felülete

1983-ban jelent meg a Broderbund kiadásában a Music Shop (2. ábra) kottaszerkesztő program. Ahogy a mellékelt ábrán is láthatjuk, a hagyományos kétsoros kotta fölött lenyíló menük helyezkednek el. A Windows operációs rendszer - melynek 1.0-ás verziója csak 1985-ben jelent meg! - ablakstruktúráján „szocializálódott” szem számára a lenyíló vagy legördülő menü megszokott, ám '83-ban ez újdonságnak számított. A piacon ekkortájt fellelhető zeneszerkesztő programokhoz képest, ahol inkább a scroll view (folyamatos nézet) kottasor megjelenítést alkalmazták, itt találunk Page view (lap- vagy oldalnézet) alternatívát is (Stuckey, 1985). Néhány további menüpont: Kivágás, Másolás, Beillesztés és Nyomtatás!

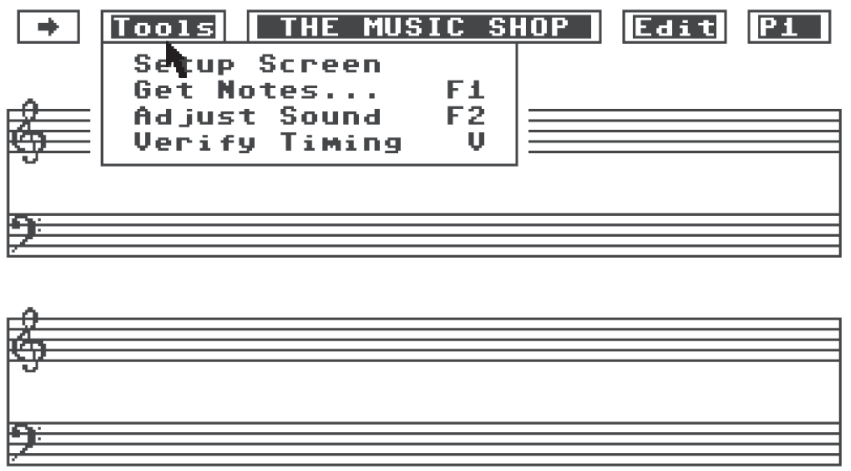

2. ábra. Music Shop - legördülö menüvel 
Itt érdemes megjegyezni, hogy a nyomtatás területén sem kellett sokat várni a robbanásra. 1984-ben a HP LaserJet, majd egy évvel később az Apple LaserWriter megjelenése forradalmasította az irodai és otthoni nyomtatást. A digitális kotta papírra került.

Will Harwey programját 1984-ban jelentette meg az Electronic Arts. A Music Construction Set megírásának története több szempontból is érdekes. Harwey 15 évesen (!) kezdett egy játékprogram szerkesztésébe, amihez zenére is szüksége lett volna. Mivel nem volt zenész, nem tudta, hogyan kell komponálni. Készített egy zeneszerkesztő programot, és egy zeneboltban vásárolt néhány zongorakotta „képét” beprogramozta (digitalizálta). A program nem csak megjelenítette a kottát, hanem le is játszotta. A történet iróniája, hogy a játékprogram megközelítőleg sem lett olyan sikeres, mint a Music Construction Set (Mitra, 2010).

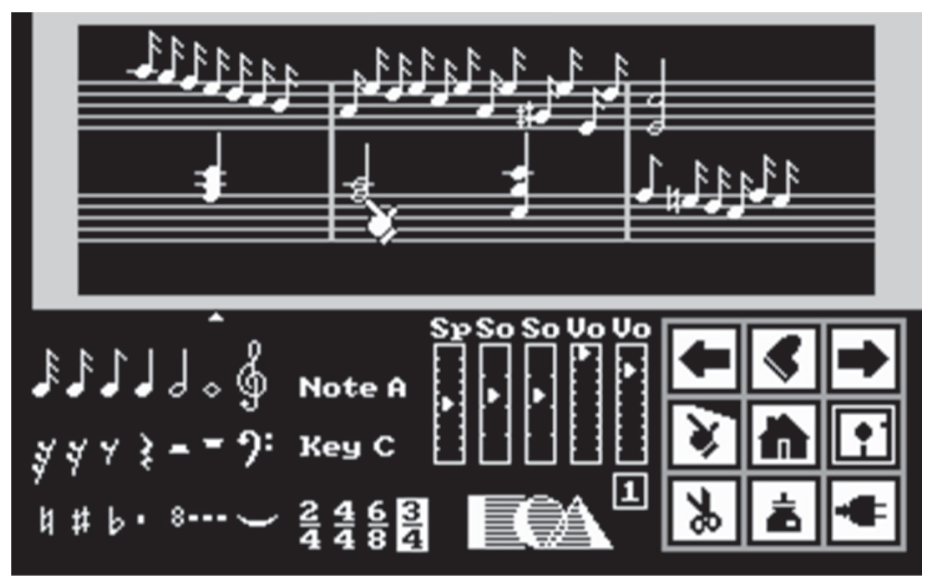

3. ábra. Music Construction Set - kottázás joystickkel

A program szórakoztatóan vezette be a felhasználót a kottázás, zeneszerzés rejtelmeibe különböző zenei stílusok segítségével. A mai kottaszerkesztő programok prototípusának tekinthető. Hátrányai elsősorban a hardverek fejletlenségének voltak köszönhetők. Grafikus felületen, drag and drop módszerrel lehetett a kottát létrehozni, melyet a gép lejátszott és ki is tudott nyomtatni, de a joystick használata viszonylag nehézkes hangjegybevitelt tett lehetővé. Ennek ellenére 1985-re az eladási adatok alapján az MCS (3. ábra) az Apple II oktatási szoftverei közt a harmadik legkelendőbb termék lett (Ciraolo, 1985).

Mivel már a Kawasaki Synthesizer és Music Construction Set kapcsán is szó esett a játszva-tanító ('edutainment') szoftverekről, érdemesnek tartok egy kis kitérőt tenni, hiszen egy pedagógiai szempontból fontos, ám jelentős mennyiségű empirikus kutatási eredmény híján sokszor vitatott állomáshoz érkeztünk.

Vygotsky már 1967-ben rámutatott arra, hogy a játék milyen fontos szerepet játszik többek között a kognitív és affektív készségek területén és a személyiség fejlődésében (Vygotsky, 1967). Ez a digitális alapokon nyugvó játékok esetében sincs másképp, de az oktatási felhasználás követelményei nem mindig találkoznak a gyártók és fejlesztők elképzeléseivel. Squire és Jenkins (2003) erről így nyilatkoznak: „Öszintén szólva, a legtöbb edutainment termék egyesíti egy rossz tanóra szórakoztató értékét egy rossz játék oktatási értékével." Ebből az idézetből is kitünik, hogy mennyire nehéz meghúzni azt a határvonalat, hogy egy számítógépes program, egy mobil applikáció vagy akár egy robot meddig játék és honnantól taneszköz, és fordítva. 
Az edutainment programok használata az alapfokú hangszeroktatás mellett elsősorban a szolfézs, a zeneelmélet és az ének-zene oktatásában lehet gyümölcsöző, hiszen az IKT-eszközök motivációs potenciálja jelentős (Condie és Mundro, 2007). Egy másik alkalmazási terület a mérés-értékelés lehet, ahol a program adatgyüjtő felületként funkcionál. A játék közben szerzett adatok mérhetik a tanuló tudását, de tanulási szokásait is számszerüsíthetik.

A számítástechnika történelméhez visszakanyarodva, egy olyan eszköz bemutatása következik, mely első sikereit játékszoftverekkel érte el, de történelmet a zenei hangok „számszerüsítésével” írt.

\section{A számítógép mint zenei munkaállomás}

Az Atari cég első korszaka (ATARI Inc.) 1972-től 1984-ig tartott. Először csak játékkonzolokat gyártottak, majd 1979-től a számítógép-piacra is betörtek. 8-bites szériájukból mintegy 2 millió darabot értékesítettek. A cég életében 1984 hozta el a nagy fordulatot. Tramiel (a Commodore alapítója) lemondott az általa létrehozott cég vezetéséről, és még ez év júliusában megvásárolta az ATARI Inc. fogyasztói divízióját, mely tartalmazta a konzol és az otthoni számítógépes osztályokat (ATARI Corporation). Jack Tramiel utasítja mérnökcsapatát, hogy egy forradalmian új, nagy tudású, emellett azonban olcsón előállítható számítógépet tervezzenek, és mindez legyen hamarabb kész, mint ahogy a Commodore által akkor már javában készített Amiga gép piacra kerül. 1985 januárjában bemutatják az ATARI ST-t, melyet grafikus felhasználói felülete miatt, Jack Tramiel-re utalva, tréfásan „Jackintosh”-nak neveznek (Banker, 1986). Az ST volt az első otthoni számítógép, melyben volt beépített MIDI-támogatás, ami miatt nagyon kedvelt lett a zenészek körében.

Látványosan inkább a könnyüzenei formációk (Mike Oldfield, Jean Michel Jarre és sokan mások) használták a gép új vívmányait stúdióban és élö fellépések alkalmával, de ez a technológia a zeneszerzők életében is új perspektívákat nyitott. A többszólamú mủvek (akár 16 szólam) rögzítése/lejátszása vált lehetővé úgy, hogy bármilyen hangszert egy MIDI billentyüzet vagy szintetizátor segítségével lehetett „feljátszani”, majd visszahallgatni, végül nyomtatni. Számos meghatározó zeneszerkesztő program kezdte ezen a konfiguráción sikertörténetét, mint például a Steinberg Cubase, vagy a Logic Pro elödje, a Notator Logic. A következő fejezetben a MIDI-vel mint „kvázi” szabvánnyal ismerkedhetünk meg.

\section{A MIDI szabvány}

1981-ben több szintetizátor-cég vezetője ült össze, hogy megvitassák egy olyan szabvány létrehozásának lehetőségét, melynek alkalmazásával az újonnan készülő szintetizátorok minden nehézség és bonyodalom nélkül összekapcsolhatóakká válnak, és teljes mértékben megértik egymást, függetlenül attól, hogy melyik gyártótól származnak. Miután a MIDI-t mint ajánlást a gyártók többsége elfogadta, el is kezdték az első hangszerek kifejlesztését és gyártását. Az 1983 januárjában tartott NAMM-kiállításon már elegendő számú, különböző gyártótól származó MIDI-s eszköz állt rendelkezésre, hogy a nagyközönség elött összekapcsolják és kipróbálják őket. Elsőként egy Sequential Circuits gyártmányú Prophet 600-ast kötöttek össze egy Roland Jupiter 6-tal - hála a MIDI-nek, a kísérlet sikerült, a Prophet és a JP6 remekül dolgozott együtt: amelyik billentyüt az egyik szintetizátoron leütötték, az a hang megszólalt a másikon (Sík-Gerényi, 2006). Ez a kísérlet az interfész életképességét bizonyította.

A számítógépgyártók, különösen a személyi számítógépekkel foglalkozók is gyorsan rájöttek a MIDI lehetőségek számítástechnikai hasznosításának lehetőségére, azaz a 
szintetizátorok számítógéppel való vezérlésének jelentőségére. A számítógép programját könnyen le lehet cserélni, ha a felhasználó másmilyet, vagy az adott program új változatát szeretné használni. A számítógép háttértárolóinak kapacitása is sokkal nagyobb, mint a szintetizátorok floppylemezére felvihető adatmennyiség.

A MIDI kapcsán, illetve a szabványosítás során egyéb kérdések is felvetődtek, például az, hogy azokon a bizonyos háttértárolókon (floppyn, merevlemezen) lévő rögzített zeneszámok rögzítési formátuma is azonos legyen. Ennek az az egyszerü oka, hogy a floppyn lévő anyagot is szeretnék hordozni a zenészek egyik rendszerből a másikba ugyanúgy, mint a hangszalagot. Ezért új szabványt kellett bevezetni, ez pedig az SMF, a Standard MIDI File (Szabványos MIDI Adatállomány) formátum (Sikk-Gerényi, 2006). Mint fájlformátum a MIDI hangfájlok viszonylag kevés helyet foglalnak el. A digitális eszközből érkező hangokat számok segítségével rögzítik.

Tekintsük át, hogy milyen digitális eszközökkel lehet MIDI információkat továbbítani! Erre a kezdetekben csak a billentyüs hangszerek (szintetizátorok) voltak képesek, de ahogy azt Rio Kawasaki kapcsán már említettem, viszonylag korán megjelentek a gitárszintetizátorok is. Elsősorban a könnyüzenészek voltak érdekeltek abban, hogy az akusztikusan megszólaló hang digitalizálva legyen. Ennek oka kettős. A stúdiókban folyó munkát nagyban megkönnyítette az eljárás, hiszen a MIDI események minden paramétere módosítható volt. Melléütés, szükségesnél hosszabb vagy rövidebb hang, vibrátó hozzáadása, hangerő, hajlítás és a többi csak néhány kattintás kérdése volt. Nem kellett újrajátszani hibás zenei részeket. A másik lehetőség az új effektusok, hangzások megszólaltatásában rejlett. Idővel megjelentek a MIDI-kompatibilis ütőhangszerek, dobfelszerelések, vonós hangszerek és fúvós kontrollerek. Ezek az előadói lehetőségek a hangszeres klasszikus zenészeket igazán nem hozta lázba, inkább a kísérletező kedvű előadók építették be ezeket az új hangzásokat zenéjükbe. Hatása azonban mégiscsak volt a MIDI beviteli eszközök fejlődésének a klasszikus zenére, a meglévő kottaállomány digitalizálásának szempontjából.

A NAMM a formátum 30 éves jubileuma alkalmából egy különleges demonstrációval bizonyította a MIDI tartósságát, értékállóságát. Egy Commodore 64-es számítógép egy külső midi interfész segítségével képes a legmodernebb iPad-del kommunikálni. ${ }^{5}$

Ennek a szabványnak a megjelenése kiküszöbölte azt a hiányosságot, mely a számítógépek korlátozott hanglejátszási (szük polifónia-lehetőség) képességei miatt kizárta a professzionális felhasználás lehetőségét. Természetesen az azóta eltelt idő alatt a MIDI formátum is követte a rohamosan fejlődő igényeket, és az újabbnál újabb zeneszerkesztő programok is hatalmasat fejlődtek és különböző felhasználói igények mentén specializálódtak. Idővel, ha nem is teljes mértékben, de szétvált a zeneszerkesztés, a kottagrafika, a virtuális szoftver hangszerek és az oktatóprogramok fejlesztése. A következő fejezetekben már nem térek ki külön a Mac OS-en, Windowson, Linuxon vagy egyéb mobil operációs rendszeren futó hatalmas mennyiségű zenei program részletes áttekintésére, csak szorosan a digitális kotta megjelenítésével, létrehozásával, alkalmazási lehetőségeivel, tárolásával és megosztásával fogok foglalkozni.

\section{A digitális kotta (Digitális kotta vs. digitalizált kotta)}

Ha valamilyen digitális eszközön megjeleníthető kottáról beszélünk, akkor azt egyszerűen csak digitális kottának szoktuk nevezni. Részletesen megvizsgálva különböző fájlformátumokat azonban jelentős eltéréseket tapasztalunk a felhasználhatóság szempontjából (még akkor is, ha van átjárhatóság a fájltípusok között). Ha az oktatásban szeretnénk tehát alkalmazni (nevezzük egyelöre így) a digitális kottát, tisztában kell lennünk a konfigurációs lehetőségekkel. Két típust különböztetünk meg: digitalizált kotta és digitális kotta. 
Papíralapú kottából valamilyen képdigitalizáló eljárás segítségével tudunk digitalizált kottát létrehozni. Ennek a müveletnek az alábbi beviteli forrásai lehetnek:

- számítógéphez csatlakoztatott külső olvasó eszköz (pl. scanner),

- digitális fényképező (digitális kamera, mobiltelefon, táblagép),

- online forrás (pl. digitális könyvtár, archívum, stb.),

- offline forrás (pl. CD/DVD, pendrive, stb.).

A létrejött fájl formátuma valamilyen képfájl (.tiff, .jpg, .bmp, stb.) vagy PDF fájl lehet. Elönye, hogy bárhol, akár mobiltelefonnal is létrehozható formátum, hatalmas online ingyenes és fizetős adatbázis áll rendelkezésre és platformfüggetlen. Hátránya, hogy csak korlátozottan szerkeszthető, a jó minőség nagy fájlmérettel jár és limitált a megjelenítési konfigurálhatósága.

Ma már elérhetőek olyan, főleg mobil eszközre készített kottaolvasó alkalmazások, melyek kimondottan a digitalizált kotta megjelenítésére specializálódtak. Joggal mondhatjuk, hogy egy PDF formátumú kotta megjelenítéséhez nincs szükség speciális programra, hiszen erre a célra számtalan ingyenes szoftver áll rendelkezésünkre. Ráadásul ezekben már van lehetőség „,ceruzás bejegyzés” létrehozására is anélkül, hogy az eredeti fájlt „,tönkretennénk”. Mégis készülnek olyan, kimondottan zenészeknek szánt digitalizáltkotta-megjelenítő programok, mint például a piaScore ingyenes alkalmazás (csak iOS-en elérhető), számos gyakorlást segítő funkcióval:

- a kotta címe alapján megkeresi a fellelhető YouTube tartalmakat,

- kottatárunkat az offline (az eszközön elérhető tartalom) forráson kívül online adatbázisok elérésével (IMSLP, Dropbox, Google Drive, e-mail, bármilyen weblap) is bővíthetjük,

- integrált hangológép, metronóm, zongorabillentyüzet, hangfelvételi lehetőség,

- lapozás érintéssel, fejbólintással vagy lapozópedállal,

- saját könytárstruktúra kialakítása,

- álló, fekvő megjelenítés,

- kiterjedt, menthető bejegyzési lehetőségek (pl. levegővétel, vonás, dinamikai jelölések, stb.).

Androidra sajnos nem létezik hasonló funkciókkal rendelkező alkalmazás, ezen a rendszeren egyelőre valamilyen PDF olvasó használatát javasoljuk.

A digitális kotta egy kottagrafikai vagy zeneszerkesztő programmal létrehozott fájl. Kiterjesztése függ a létrehozó programtól, de a szabványosítási törekvések eredményeként a MIDI formátum mellett a Music XML fájlkiterjesztés is egyre elterjedtebb. A digitális kotta előnye, hogy szerkeszthető, kicsi a fájlméret, egyre növekvő méretű online ingyenes és fizetôs adatbázisa érhető el, és szerkeszthetősége révén a megjelenítése jól konfigurálható. Hátránya, hogy a megjelenítő eszközön speciális program megléte szükséges, inkább platformfüggő és létrehozása időigényesebb. Számtalan professzionális kottaszerkesztô program létezik, és ahogy a hardvergyártóknál láthattuk, a szoftvergyártók is fontos piacnak tartják az oktatást. Termékeik árát mennyiségi licencekkel, osztálytermi, tanári verziókkal, oktatási csomagokkal, tartalmakkal igyekeznek vonzóbbá tenni. Két meghatározó cég nevét szeretném kiemelni, akiknek a termékeiről még a későbbiekben fogok szólni. Az egyik az Avid Technology, Inc. ${ }^{6}$, a Sibelius és sok más multimédiás (audio/video) szoftver és megoldás fejlesztője. A másik a MakeMusic Inc. ${ }^{7}$, a Finale kottaszerkesztő, a Garritane minőségi virtuális szoftver hangszerek, a Music XML és a SmartMusic interaktív zeneoktató program fejlesztője.

Nem csak pénzért tudunk minőségi szoftverekhez jutni. Az alább felsorolt programok nyílt forráskódúak, több operációs rendszeren futnak, saját - akár többezres - kottabázissal rendelkeznek ingyen. 
- LilyPond ${ }^{8}:$ „Egy nyílt forrású kottaszedő program, mely a lehető legjobb minőségű kotta előállítására képes. Ez a szabad szoftver a hagyományos, kézzel szedett kották szépségét adja vissza."

- Mutopia Project ${ }^{9}$ : több mint 1500 klasszikus zenemü szabadon letölthetö kottájával a LilyPonddal szedett kották online tárháza.

- MuseScore ${ }^{10}$ : Ingyenes, szintén nyílt forrású kottaszerkesztő program. Jelenleg 2.0-ás verziója Windows-on, Linuxon és Mac OS X-en futtatható. A mobil platformokon futó alkalmazások nem ingyenesek vagy csak korlátozott funkciókkal ingyenesek. A program weblapjáról, vagy közvetlenül a programból több ezer kotta tölthető le ingyenesen, többféle formátumban, melyek aztán a MuseScore-ban tetszés szerint szerkeszthetőek.

A felsorolt programok jellemzője még, hogy a közösségi tevékenységben általában nagyon aktívak, sőt erre projekteket is alapoznak. Nemrégiben a crowdsourcing munkaszervezés formában létrehozott Goldberg variációk ${ }^{11}$ és a Wohltemperiertes Klavier ${ }^{12}$ kottáját tették közkinccsé. Mi is az a crowdsourcing? „A crowdsourcingot magyarra közösségi ötletbörzeként is fordíthatjuk, de ez a kifejezés teljes mértékben nem alkalmas az angol megfelelö teljes jelentéstartalmának lefedésére. A crowdsourcing egy olyan folyamat, melynek során vállalatok, állami szervezetek kreatív tevékenységük bizonyos részeit „kihelyezik” a közösség felé. A tevékenységet kihelyezők a legjobb feladatmegoldásért, megoldásokért felajánlhatnak bizonyos pénzösszeget vagy munkalehetőséget (Szücs és Jinil, 2013).

\section{Digitalizált kotta + OCR $=$ Digitális kotta}

Mint azt már említettük, van azonban átjárhatóság a formátumok között. Az egyszerübb eljárás a digitális kottából „digitalizáltat” csinálni, azaz képfájlt vagy pdf-et - bár ennek elsőre látszólag nincs értelme, de vannak felhasználási szituációk, amikor mégis szükséges ez az átalakítás. A kottaszerkesztő program export menüpontjában kiválasztjuk a kimeneti fájltípust, és egy gombnyomással kész a művelet. A digitalizált kotta átalakítása digitális kottává azonban már sokkal bonyolultabb eljárást igényel. Ez a technológia az OCR (4. ábra), azaz az Optical Character Recognition (optikai karakterfelismerés). Az eljárás lényege, hogy egy nyomtatott szöveg vagy kotta képét a feldolgozó szoftver felismeri és átalakítja szerkeszthető fájlformátummá, például szöveg- vagy midi fájllá. Ez a folyamat felgyorsítja a digitalizálást, archiválást, hiszen nem kell manuálisan egy szöveget újragépelni, vagy egy kottát újraszedni.

Az egyik legkorábbi OCR-képes kottázó programot 1991-ben a Musitec Corporation adta közre MIDISCAN for Windows néven. A későbbiekben átkeresztelték és - 1998ban Windows 98-ra, 1999-ben pedig Power Macintosh-ra - SmartScore név alatt adták ki. A legfrissebb verzió 2013-ban jelent meg SmartScore X2 néven. A program felismeri a nyomtatott kotta digitális fotóját, melyet MIDI vagy XML formátumba konvertál. 2009-ben a Music Educators Journal cikke szerint a program rendkívül precízen ismeri fel a nyomtatott kottákat, de a kézzel írott anyagok esetében csak minimális a felismerési arány (Michlin, 2009). 


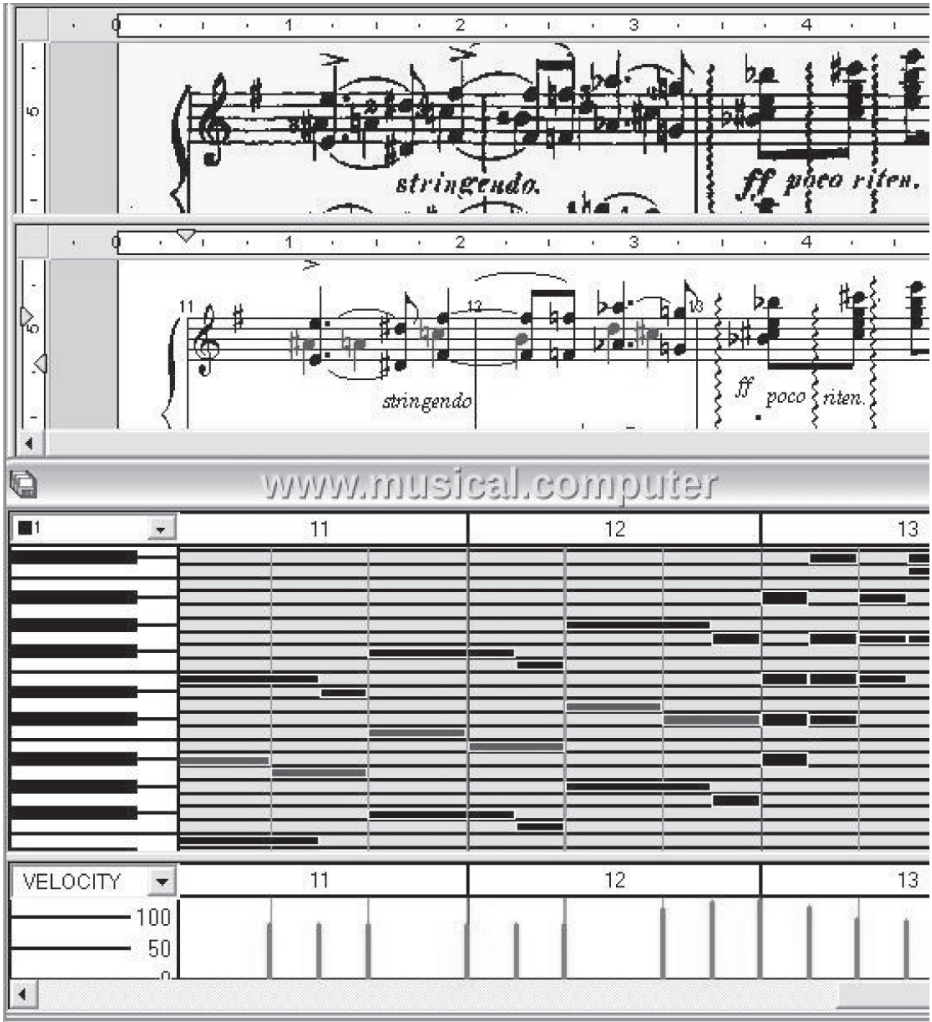

4. ábra. A SharpEye munka közben. Digitalizált kotta (felsö ablak), digitális kotta (középső ablak), MIDI bejegyzések (alsó ablak)

Ha kottafelismerésről van szó, meg kell említenünk a Sibelius Software programjait. Szerintük termékük a világ legkelendőbb kottaszerkesztő programja „,100 országban, többszázezer felhasználó”-val. Kétségtelen tény, hogy zeneszerzők, hangszerelők, kiadók, tanárok, diákok egyaránt preferálják ennek a programnak a használatát. Windows-os és Mac verziója 1998-ban jelent meg. A kottázóprogram egyik kiegészítője a PhotoScore Lite, de ennek teljes verziója, a PhotoScore Ultimate (jelenleg a 7-es verziónál tart, ára: 250 USD) a nyomtatott kották mellett a kézzel írott kottákat is nagyon jól felismeri.

Számtalan további fizetős OCR program létezik, de két ingyenes alkalmazás szeretnénk mindenki figyelmébe ajánlani: OpenOMR ${ }^{13}$ és Audiveris. ${ }^{14}$

\section{MusicXML - Az új digitális kottaszabvány}

A MusicXML formátum a Makemusic terméke. Napjaink legsikeresebb és legelterjedtebb digitális kotta szabványa a MIDI óta. Az 1.0-ás verzió 2004-ben jelent meg, jelenleg a 3.0-ás verziónál tart. A fejlesztők célja egy olyan univerzális fájlformátum létrehozása volt, mely biztosítja az átjárhatóságot a többszáz kottamegjelenítésre, szerkesztésre alkalmas szoftver között, és kis mérete miatt „webbarát”.

2015. április 17-én, a http:/www.musicxml.com/software/ forrása alapján, csak az asztali operációs rendszereken futó programok közül 194 képes a MusicXML kezelésére, 
és ebben még nincsenek benne a mobil rendszereken futó alkalmazások. A kis fájlméret miatt az online/offline megosztás, tárolás és bármilyen szerkesztési eljárás gyorsan véghezvihető. Nyílt forráskódú és ingyenes. Mivel alapjában véve ez egy szöveges formátumú fájl, ezért akár egy egyszerü jegyzettömb segítségével elkészíthető, szerkeszthető. Ez a szerkesztési mód igényel némi programozási ismeretet, ezért sokkal elterjedtebb a kottázóprogramon belüli szerkesztés.

\section{Kottaforrások}

Ha nem magunk szeretnénk digitális kotta szedésével vagy feljátszásával foglalatoskodni, akkor számos ingyenes és fizetős forrás áll rendelkezésünkre. Már az előzőekben említett kottaszerkesztő és -megjelenítő alkalmazások által kínált tartalmon túl webáruházak kínálják digitális vagy digitalizált kottáikat, éves díj fejében iskoláknak akár korlátlan darabszámú nyomtatási lehetőséggel is.

Ha már az előző fejezetben a MusicXML formátummal foglalkoztunk, abból a digitális kottaforrás-ajánlásból emelnék ki néhányat, melyet a http://www.musicxml.com/ music-in-musicxml/ oldalon találunk:

- Musicalion ${ }^{15}$ : Előfizetés-alapú online könyvtár, több mint 31077 kompozícióval (2015. 04. 17.) Ebből több mint 11000 MusicXML formátumban. Éves előfizetés $29 €$. Fájlformátumok: MusicXML, PDF, MIDI, eredeti program formátumok.

- MuseScore.com ${ }^{16}$ : Ingyenes letöltést biztosít a MuseScore felhasználói közössége által létrehozott fájlokhoz. Fájlformátumok: MuseScore, MusicXML, PDF, MIDI és MP3.

- IMSLP Petrucci Music Library ${ }^{17}$ : IMSLP, az International Music Score Library Project. Az online elérhető közkincsek egyik legnagyobb gyüjteménye. 2015. március 28-án 310000 kotta érhető el az oldalon. Fájlformátumok: PDF, MusicXML, MIDI, MP3.

- Choral Public Domain Library ${ }^{18}$ : A könyvtárban több mint 20000 kórus és vokális közkincs érhető el. Fájlformátumok: MusicXML, Finale, Sibelius, Capella, Myriad, stb.

- Open Music Score ${ }^{19}:$ Az oldal célja a közkincs kották megosztása. Fájlformátum: MusicXML.

- Gutenberg Project ${ }^{20}$ : A Gutenberg project kotta szekciója. Fájlformátumok: MusicXML, Finale.

Az alábbi oldalak inkább üzleti vállalkozásként müködnek, de csekély ingyen tartalmat is kínálnak. Az USA-ban működő kereskedők az európai áraknál jóval olcsóbban árusítják kottáikat, és professzionális terméktámogatással rendelkeznek.

- http://www.emb.hu, http://www.sheetmusicplus.com/, http://www.onlinesheetmusic.com/,

- http://www.sheetmusicdirect.com/

\section{A digitális kotta tárolása}

Számos forrást és lehetőséget ismerhettünk meg az előző fejezetekben, joggal merül fel a kérdés, hol és hogyan tároljuk meglévő adatainkat. Ha abból indulunk ki, hogy meglévő digitális kottatárunkat oktatási célokra szeretnénk használni, az alábbi szempontokat érdemes figyelembe venni: 
- Érdemes gyakran menteni legalább két példányban meglévő adatainkat.

- Hasznos, ha legalább az egyik mentésünket valamilyen felhö alapú szolgáltatásban tároljuk.

A felhő alapú szolgáltatásban való tárolásnak számos előnye lehet. „A felhő alapú számítástechnika (angolul »cloud computing«) a számítástechnika egyik ágazata. Többféle felhő-alapú szolgáltatást különböztethetünk meg, a közös bennük az, hogy a szolgáltatásokat nem egy dedikált hardvereszközön üzemeltetik, hanem a szolgáltató eszközein elosztva, a szolgáltatás üzemeltetési részleteit a felhasználótól elrejtve. Ezeket a szolgáltatásokat a felhasználók hálózaton keresztül érhetik el, publikus felhő esetében az interneten keresztül, privát felhő esetében a helyi hálózaton vagy az interneten. A felhő alapú számítástechnika a 2010-es évek egyik fố irányának számít a digitális technológia területén.

- Helyfüggetlen: Egy felhő-alapú megoldás (főleg publikus felhő) esetében a szolgáltatás bárhonnan könnyen elérhetö lehet. A szolgáltatás maga is lehet független egy adott szerverközponttól.

- Méretezhető: A »cloud computing« alkalmazásával megszűnhet az az aggodalmunk, hogy mi történik, ha megnövekszik a tárhelyigényünk, ugyanis a felhő szolgáltatásai méretezhetőek.

- Nagy rendelkezésre állás: A felhö-alapú szolgáltatások mögött meghúzódó cégek folyamatos fejlesztése és komoly beruházásai, hatalmas adatbankjai jelentik a garanciát arra, hogy a szolgáltatások világszínvonalon és megfelelő minőségben álljanak rendelkezésre.

- Költségkímélö: A hardvereszközök megvásárlásának költségét a szolgáltatás használatának díja váltja fel - ez például lehet a bérelt számítási kapacitás, a hálózati forgalom vagy a felhasználók száma alapján kiszámolt összeg. A müködtetési feladatok nem a felhasználókat terhelik. Az alkalmazások frissítésének járulékos költségei is megtakaríthatók." 21

Megfelelő hardveres, szoftveres háttérrel és szaktudással mi vagy iskolánk is üzemeltethet felhő-alapú szolgáltatást. Ezek hiányában többek között az alábbi szolgáltatók kínálatából is választhatunk, igényeinktől függően ingyen vagy valamilyen díj ellenében.

- Dropbox: Alapértelmezésben 2 GB tárhelyet biztosít ingyen, de ez tovább növelhető ismerősök meghívásával, számítógépes szinkronizáló program feltelepítésével, Facebook- és Twitter-fiók csatolásával, mobileszköz kamerájának szinkronizálásával és a bemutató megtekintésével, közel 20 GB-ot tudunk bővíteni, de Samsung készülék vásárlása mellé plusz 50 GB jár. Minden vezető asztali és mobil operációs rendszerre létezik szinkronizáló applikációja. Könyvtárainkat, fájljainkat megoszthatjuk ismerőseinkkel (tanulóinkkal), akikkel kollaboratív munkát is végezhetünk.

- Google Drive: A Google termékskálájának egy darabja. 15 GB tárhelyet kapunk ingyen, de promóciós kedvezmények révén itt is volt/van lehetőség extra ingyen tárhely bővítésre. Szorosan együttmüködik más Google applikációkkal, ami egy Gmail címmel rendelkező felhasználó számára komfortos munkakörnyezetet teremt. A Google Docs applikáció segítségével real-time együttmüködésben tudjuk dokumentumainkat szerkeszteni. Minden vezető asztali és mobil operációs rendszerre létezik szinkronizáló applikációja. 
- OneDrive (előtte SkyDrive): A Microsoft tárhely szolgáltatása 15 GB ingyen tárhellyel, de további 500 MB-t kapunk minden meghívott ismerősünk után. Ha bekapcsoljuk mobiltelefonunk filmtekercs biztonsági mentésének funkcióját, plusz 15 GB tárhelyet kapunk. Windows-ra, Windows Phone-ra, Xbox-ra, iOS-re és Androidra készült szinkronizáló applikációja. A teljes, telepített Office-alkalmazásokat, így a Wordöt, az Excelt és a PowerPointot használók, plusz 1 TB online tárhelyet is kapnak.

Bármelyik online tárolási megoldást választjuk, az itt fellelhető fájlokat növendékeinkkel megosztva, tartalomszolgáltatókká válunk. Lehetőség van, más kollégákkal együttmüködve is akár, továbbfejleszteni, bővíteni tudástárunkat, hiszen egyéb tanulást segítő tartalmak (fogástáblázatok, befúvó, bemelegítő gyakorlatok, egyéb szakmai anyagok) megosztása is lehetséges. Az elérhető tartalmak felhasználási feltételeiről, esetleges jogi korlátokról mindenképpen tájékoztassuk tanulóinkat.

\section{A digitális kottatartó}

Az elkészített vagy letöltött digitális kotta megjelenítésénél ismét érdemes több szempontot is figyelembe venni. Véleményem szerint az egyik legfontosabb a képernyő mérete és a képmegjelenítés minősége. A legelterjedtebb képernyőméretek laptopok esetében a 10-15 col, asztali gépek esetében a 14-21 col és mobil eszközök (értsd: inkább táblagépek) esetében 10,1-12 col. Kottaolvasásra ez utóbbi méret alatt nem is javasolnék eszközt, és ebben az esetben is inkább landscape (fekvő) nézetben. A kottaolvasási tradíciókat figyelembe véve, ha a valós méretben gondolkodunk, egy darab, álló A4-es méretü lap megjelenítése egy 15 colos monitor elfordított képernyőjére fér rá, vagy két darab, álló A4-es méretü lap megjelenítése egy 21 colos monitoron jeleníthető meg. Az eszköz kiválasztásánál azt is érdemes figyelembe venni, hogy a kottaolvasó állva vagy ülve fog játszani, tehát a képernyő elhelyezésének a hangszerjátékos szempontjából ergonomikusnak kell lennie. Kardinális kérdés szokott lenni még a lapozás. Ez megint a hardverkombináció határozza meg. Ha a hagyományos asztali PC vagy laptop használatából indulunk ki, akkor egérrel vagy billentyüvel tudunk lapozni, ami a játékos számára szinte kivitelezhetetlen. Létezik azonban két másik megoldás:

1. Bluetooth-os lapozópedál használata.

2. Érintőképernyős monitor használata.

Ha valaki nem szeretne a hardverek és szoftverek konfigurálásával bajlódni, kész megoldások is találhatók a piacon. Az egyik ilyen a Continuum és eInk (5. ábra) közös digitális kottatartója, ami tulajdonképpen egy nagyméretü ebook, kottabejegyzési, mentési, megosztási funkcióval, beépített mikrofonnal mely hallgatja a zenét és lapoz. A másik ilyen kombó a MusicOne CV24, ami egy 24 colos All-in-One számítógép, Windows 8.1 operációs rendszerrel, 64 GB tárhellyel, WIFI-vel, lapozópedállal és előre telepített PowerMusic Professional szoftverrel. 


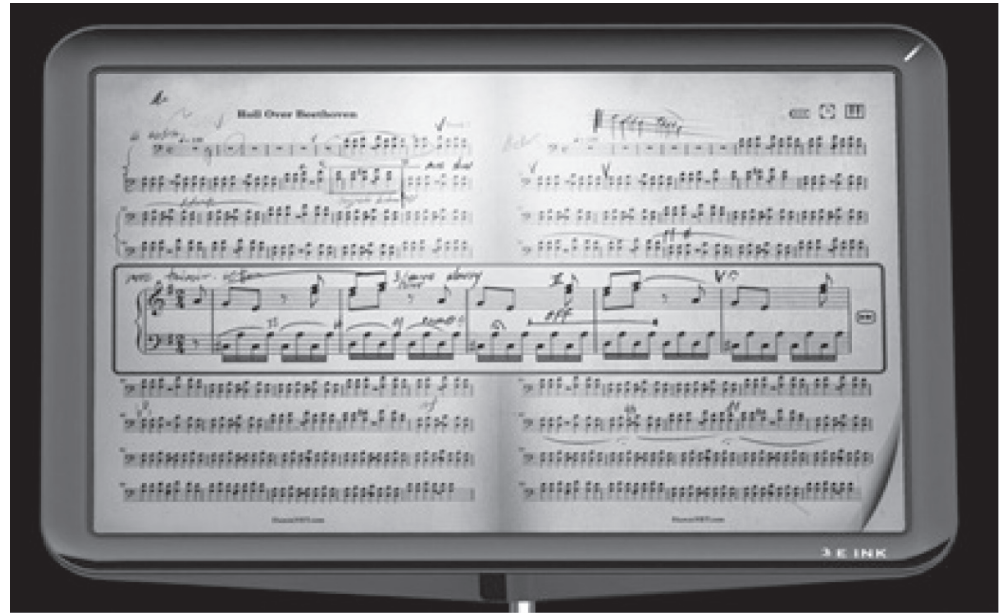

5. ábra. Kottakép az eInk kijelzöjén

Amennyiben mobil eszközt választunk a kotta megjelenítéséhez, az elhelyezés és lapozás szempontjából könnyebb dolgunk lesz. Egy hagyományos mikrofonállványból és egy vele kompatibilis táblagép-tartóból pillanatok alatt készíthetünk könnyen szállítható és állítható „kottatartót”. Már csak a digitális eszközt kell a helyére pattintani a használathoz. Itt azonban a képernyőméret - elérhető áron egyelőre csak 10,1 colos méretü táblagépet kapunk - jelenthet gondot. Ezen a ponton kap jelentőséget az, hogy milyen hardvert és szoftvert használunk. Három programot szeretnék ajánlani azoknak, akik ezt a konfigurációt választják osztálytermi kottatartóként.

- Tonara: Ingyenes kottaolvasó szoftver csak iOS-re. Emellett metronóm, hangfelvevő, MAGIC funkció ${ }^{22}$ található a program szolgáltatásai között. Midi, PDF és saját formátum importja netről, Dropboxból, e-mailből, Google Drive-ból, saját áruházából és az IMSLP-ről.

- MuseScore: Kottaolvasó és lejátszó szoftver. Import saját könyvtárból és a saját MuseScore ingyenes több ezer kottát tartalmazó adatbázisból. Transzponál, emellett metronómot, szólamonkénti hangerőszabályzót, tempóállítást tartalmaz. Ára az App Store-ban \$5,99, a Google Play áruházban „lite verzió” ingyenes, teljes verzió kb. $2000 \mathrm{Ft}$.

- Avid scorch: Kottamegjelenítő. A pdf fájlok beolvasása mellett a midi és xml fájlokat is kezeli, lejátssza, transzponálja (16. ábra), és a tempót az általunk beállítottra módosítja. Saját áruháza is van. Ára az App Store-ban \$1,99. 


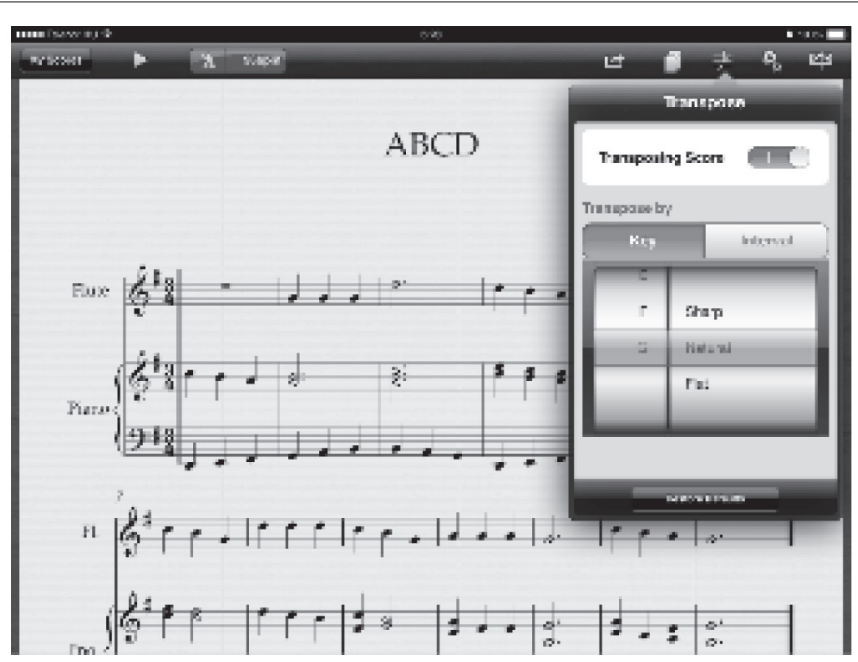

6. ábra. Az Avid Scorch transzponálás közben

\section{SmartMusic, az asszisztens}

A Makemusic terméke a SmartMusic interaktív zeneoktató szoftver, melynek kotta-motorja a Finale. A keretprogram ingyenesen letölthető és kipróbálható Windows-ra, Mac OS-re és iOS-re (sajnos Androidon egyelöre nem elérhetö). A program teljes szolgáltatásainak elérése díjköteles. A tanulóknak 44 USD/év, az oktatóknak 140 USD/év a „tagsági díj”. Lehetőség van osztálytermi licence megvásárlására, ez 44 USD/év. A SmartMusic weblapjának (www.smartmusic.com) információi alapján ez egy díjnyertes szoftver, melyet zenepedagógusok használnak világszerte, hogy módszertani eszköztárukat bővítve nagymértékben javítsák növendékeik felkészültségét. Központban a diák gyakorlása áll, ugyanis a zongora- vagy zenekari szólamokkal kísért eljátszást követően (melyet a számítógép rögzít) azonnali visszajelzést kapunk arról, hogy milyen hangmagassági és ritmikai precizitással játszottuk le a képernyőn látott kotta képét. A felvétel vissza is hallgatható vagy azonnal megosztható a tanárral, aki így két tanítási óra között is segítheti tanácsaival a tanulót. Az előfizetés fejében talán a világ legnagyobb, nagyon jó minőségü kísérettel ellátott digitális kottatárához férhetünk hozzá. A személyre szabott gyakorlást számtalan eszköz és finomhangolási lehetőség támogatja, úgymint:

- azonnal transzponálható kottaanyag,

- intelligens lapozás,

- hangológép,

- metronóm,

- tempóállítási lehetőség,

- gyakoroltatás X ütemszámtól Y ütemszámig,

- a kottában lévő bármely hangra kattintva fogás-segédlet jelenik meg,

- hibás hangok pirossal, jól játszott hangok zöld színnel jelezve,

- saját szólam játszásának ki/bekapcsolása,

- a kíséret követi a játékost (igaz, korlátozott keretek között, de beállíthatóak elöre meghatározott hangok, melyeket ha nem szólaltat meg a játékos, a kíséret „,bevárja"),

- a gyakorlás végeztével a program értékelése százalékosan. 


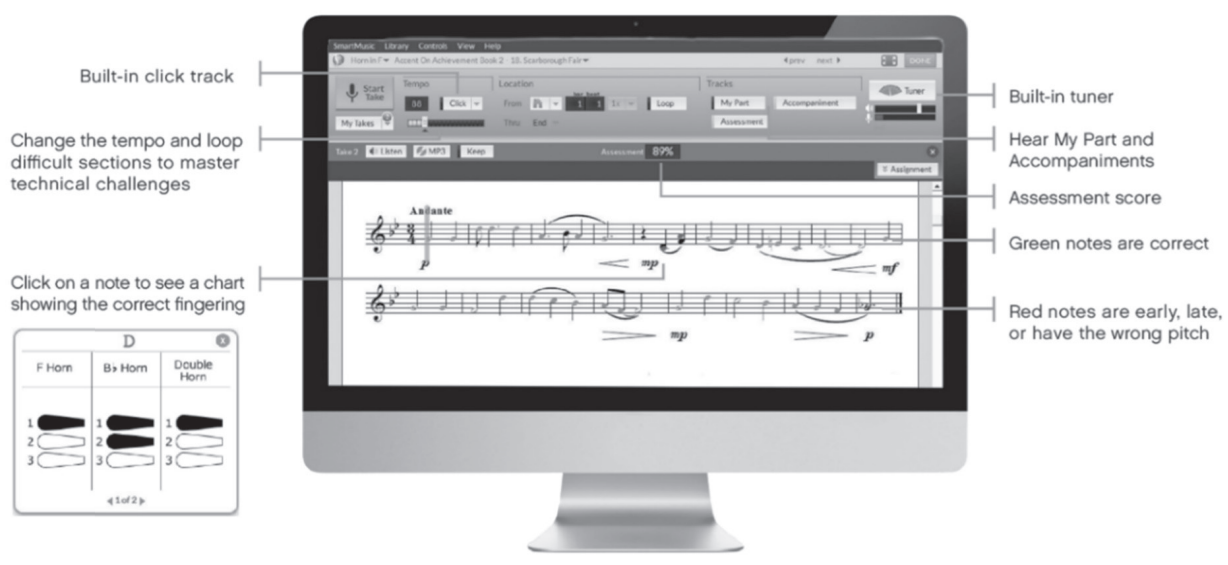

7. ábra. A SmartMusic kezelöfelülete

A csak a tanár által elérhető funkciókról is érdemes néhány szót ejteni. A diák által elküldött gyakorlást rögzítő fájlt a tanárnak lehetősége van meghallgatni, értékelni, kommentálni, szükség esetén újra feladni. Látja azt, hogy a tanuló a feladott anyagot milyen tempóban és mennyi időt gyakorolta. Ezenkívül egy komplett haladási és osztályozási napló is a tanár rendelkezésére áll, melyben minden végzett anyag értékeléssel együtt nyomon követhetö.

Ha nem lenne elég az a több mint 4000 zenekari/kamara anyag, 18000 szólódarab (értsd szólóhangszer vagy ének+kíséret), 600 lapról olvasó gyakorlat és skálagyakorlat, akkor a Finale programból bármilyen általunk elkészített vagy előkészített zenei anyag közvetlenül exportálható SmartMusic-kompatibilis fájlba.

Összefoglalva elmondhatom, hogy a gyakorlatban szerzett tapasztalataimat is figyelembe véve a SmartMusic használata a gyermekek számára nagyon inspiráló. Meg kell hallanunk azonban a kétkedők potenciális érveit is: (direkt sarkítva) „Ezek miatt a programok miatt elveszítem hangszertanári/korrepetítori állásomat!" És a tanulók aspektusáról se feledkezzünk meg. Ezek a programok „viszik” vagy „hozzák” a gyereket? - mármint abból a szempontból, hogy ha valamelyik növendékünkkel megismertetjük ezt a szoftvert, akkor két hónap múlva kiíratkozik a zeneiskolából, mert a SmartMusic mindenre megtanítja. Két dolgot érdemes leszögezni:

1. Az interaktív zeneoktató program nem alkalmas arra, hogy bárkit is megtanítson egy hangszeren játszani. Nem tudja megmondani, hová vegyük a levegőt (egyáltalán mi az a rekeszizom?), hogyan tartsuk a kezünket, hogy álljunk, hogy vibráljunk, mi az a crescendo, mit érezzünk játék közben, és még az az ezernyi információ, ami egy pedagógus fejében, szívében ott van, és amit helyzetfüggően bármikor tud alkalmazni. Ez egy eszköz, egy tanári asszisztens, a tanuló számára pedig egy motiváló gyakorlási környezet.

2. Nem helyettesíti a zongorakísérőt, mert bár valóban fantasztikus lehetőségek rejlenek a program használatában, de egy másik személlyel való együttjáték izgalmát és örömét, a zene megszületésének varázsát, mely mindig egy megismételhetetlen pillanattal ajándékozza meg a hallgatót, egy intelligens gép sem tudja pótolni. 


\section{Az utolsó szó jogán}

Akár a digitális tartalomról, akár zenemüről vagy előadásról beszélünk, egy nagyon fontos kérdést nem hagyhatunk figyelmen kívül, ez pedig a szerzői (és előadói) jog.

„A technikai fejlődéssel lépést tartó, korszerü szerzői jogi szabályozás meghatározó szerepet tölt be a szellemi alkotás ösztönzésében, a nemzeti és az egyetemes kultúra értékeinek megóvásában;" ezzel a bekezdéssel kezdődik a hatályos szerzői jogi törvény, majd később ezeket a paragrafusok kapcsolódnak szorosan témánkhoz:

„23/A. § (1) A nyilvános haszonkölcsönzést végző könyvtárakban haszonkölcsönzés útján terjesztett irodalmi mủvek és kottában rögzített zenemüvek szerzőit a haszonkölcsönbe adásra tekintettel megfelelő díjazás illeti meg.

31. § (1) A szerzői jogok a szerző életében és halálától számított hetven éven át részesülnek védelemben.

35. § (1) Természetes személy magáncélra a müről másolatot készíthet, ha az jövedelemszerzés vagy jövedelemfokozás célját közvetve sem szolgálja. E rendelkezés nem vonatkozik az építészeti müre, a müszaki létesítményre, a szoftverre és a számítástechnikai eszközzel müködtetett adatbázisra, valamint a mü nyilvános elöadásának kép- vagy hanghordozóra való rögzítésére. Kotta reprográfiával [21. $\S$ (1) bek.] magáncélra és a (4) bekezdés $b$ )-d) pontjában szabályozott esetekben sem többszörözhetö."

Amennyiben a hetven év letelt, a kotta elvileg szabadon másolható. A törvényben a „kotta” kifejezést csak két helyen találhatjuk meg, és a digitális (nem digitalizált) kotta fogalma sem fellelhetö. Annak ellenére, hogy a tanulmányban többször találkozhattunk a digitális kották kapcsán a közkincs fogalmával, sajnos ez a terminus sincs meg a magyar szerzői jogban. Az IMSLP wiki oldalán ezt olvashatjuk: „A 'közkincs' jelentése, hogy a szellemi termék nem áll szerzői jog védelme alatt, és szabadon terjeszthető. [...] Az európai unióban egy zenemü akkor számít közkincsnek, ha mindegyik szerzö/szerkesztő/szövegíró legalább 70 éve meghalt. [...] Azok a »tudományos« vagy úgynevezett »Urtext« kiadványok - vagyis amikor a szerkesztő(k) a szerző eredeti munkájának közlésén túl semmilyen hozzáadott értéket nem adnak -, az EU-ban legfeljebb 30 évig állnak szerzői jogok védelme alatt."

Összevetve a zenészek, zenetanárok kottamásolási „gyakorlatát” a szerzői jogi törvénnyel, érezhetünk némi diszharmóniát, de ennek feloldása már egy másik kutatás témája lehet.

\section{Irodalomjegyzék}

1999. évi LXXVI. törvény a szerzői jogról

Ahl, D. H. (1984): The first decade of personal computing. Creative Computing, 10. 11. sz. 30.

Banker, S. (1986): Jack Tramiel - A Candid discussion. Start, 1. 3. sz.

Búzás Zsuzsa (2012): Információs és kommunikációs technológia alkalmazása a zeneoktatásban - a hagyományostól a modern módszerekig. Parlandó, 5. sz.

Byte Magazine (1995): Most Important Companies. Byte, September 6-10.

Carlson, E. H. (1983): Teach your kids programming. Creative Computing, 9. 4. sz. 168.
Ciraolo, M. (1985): Top Software. II Computing, 1. 1. sz. 53. 2015. 04. 21-i megtekintés, https://archive.org/ stream/II_Computing_Vol_1_No_1_Oct_Nov_85 Premiere\#page/n51/mode/2up

Condie, R. és Munro, R. (2007): The impact of ICT in schools - a Landscape Review. Becta Research, 4.

Dillon, A. (1992): Reading from paper versus screens: a critical review of the empirical literature. Ergonomics, 35. 10. sz. 1297-1326. DOI: 10.1080/00140139208967394

Forster, W. (2005): The encyclopedia of consoles, handhelds \& home computers 1972-2005. GAMEPLAN, 18. ISBN 3-00-015359-4. 
Frucht, L. (1982): Computers bring the 21st century to five-year-olds. The Gazette Montreal, B5.

Griggs, B. (2011): The Commodore 64, that '80s computer icon, lives again. 2015. 04. 21-i megtekintés, http://edition.cnn.com/2011/TECH/gaming. gadgets/05/09/commodore.64.reborn/

Gröger, M. (1999): Apple II - starting the personal computer boom. 2015. 04. 21-i megtekintés, http:// www.silicon-valley-story.de/sv/apple_appleII.html

Smith, G. (2012): Commodore pioneer Jack Tramiel dies: Wozniak, industry and tech pros react. TechRepublic, 2015. 04. 21-i megtekintés, http:// www.techrepublic.com/blog/tech-decision-maker/ commodore-pioneer-jack-tramiel-dies-wozniakindustry-and-tech-pros-react/

Janurik Márta (2007): Áramlatélmény az iskolai ének-zeneórákon. Magyar Pedagógia, 107. 4. sz. 295-320

Janurik Márta és Pethő Villő (2009): Flow élmény az énekórán: A többségi és a Waldorf iskolák összehasonlító elemzése. Magyar Pedagógia, 109. 3. sz. 193-226.

Mangen, A., Walgermo, B. R. és Brønnick, K. (2013): Reading linear texts on paper versus computer screen: Effects on reading comprehension, International Journal of Educational Research, 58. 61-68. DOI: 10.1016/j.ijer.2012.12.002

McCrindle Research (2014): Generation Z. 2015. 04. 21-i megtekintés, http:/www.generationz.com.au/

Miller, M. J. (2011): The Rise of DOS: How Microsoft Got the IBM PC OS Contract Forward Thinking. 2015. 04. 21-i megtekintés, http://forwardthinking. pcmag.com/software/286148-the-rise-of-dos-howmicrosoft-got-the-ibm-pc-os-contract

Michlin, A. (2009): SmartScore X Music. Educators Journal, 95. 4. sz. 16.
Mitra, S. (2010): Learning From Failures: IMVU Founder Will Harvey. 2015. 04. 21-i megtekintés, http://www.sramanamitra.com/2010/08/01/learningfrom-failures-imvu-founder-will-harvey-part-1/

Picking, R. (1997): Reading music from screens vs paper, Behaviour \& Information Technology, 16. 2. sz. 72-78. DOI: 10.1080/014492997119914

Raf/Samar (2003): Ryo Kawasaki (interview). 2015. 04. 21-i megtekintés, http://www.ryokawasaki.com/ c64/uncover/artview_php.htm

Rucz Lajos és Székely László (1989): Bejelentkezés. Commodore Világ, 1. sz. 1.

Sandler, C. (1984): IBM: colossus of Armonk. Creative Computing, 10. 11. sz. 298.

Squire, K. és Jenkins, H. (2003): Harnessing the power of games in education. In sight, 3. 8. sz.

Stuckey, S. (1985):. Boys Life, 65. Creative Computing

Sík Zoltán és Gerényi Szilvia (2006): MIDI. Alapozás és protokoll. http://mek.oszk.hu/11800/11879/11879. pdf

Szüts Zoltán és Yoo Jinil (2013): A magyar civil crowdsourcing és crowfunding jó gyakorlatai. Civil Szemle, 3. sz. 31-43.

Terdiman, D. (2013): The untold story behind Apple's $\$ 13,000$ operating system. 2015. 04. 20-i megtekintés, http://www.cnet.com/news/the-untold-storybehind-apples-13000-operating-system/

Vygotsky, L. S. (1967): Play and its role in the mental development of the child. Soviet Psychology, 5. 3. sz. 6-18. DOI: 10.2753/rpo1061-040505036

Waters, A. (2015): How Steve Jobs Brought the Apple II to the Classroom. 2015. 04. 21-i megtekintés, http://hackeducation.com/2015/02/25/kids-cant-waitapple/ 


\section{Jegyzetek}

${ }^{1}$ A zenei értelemben vett bevezetést a ,könnyűzenében” az 'Intro', a „klasszikus zenében” az 'Introduction' kifejezéssel jelzik.

${ }^{2}$ Ld.: Útmutató a pedagógusok minősítési rendszeréhez, Alapfokú művészetoktatás - Zeneművészeti ág (egyéni zenei képzés).

${ }^{3}$ OECD, TALIS 2013 Database, Table 2.1.

${ }^{4}$ https://www.youtube.com/watch? $=$ FWk2iDyZOPAA

5 http://www.engadget.com/2013/01/25/ midi-turns-30-commodore-64-animoog/ - 2015. 03. 27.

${ }^{6}$ http://www.avid.com/US

${ }^{7}$ http://www.makemusic.com/

${ }^{8}$ http://www.lilypond.org/

${ }^{9}$ http://www.mutopiaproject.org/

${ }^{10} \mathrm{http}: / /$ www.musescore.org/

${ }^{11}$ http://musescore.com/opengoldberg/goldberg-variations\#
${ }^{12}$ http://musescore.com/opengoldberg/sets/openwtc

${ }^{13} \mathrm{http}: / /$ sourceforge.net/projects/openomr

${ }^{14}$ https://audiveris.kenai.com/

15 http://www.musicalion.com/

${ }^{16} \mathrm{http}: / /$ www.musescore.org/

${ }^{17}$ http://www.imslp.org/

${ }^{18}$ http://www1.cpdl.org/wiki/index.php/Main_Page

${ }^{19} \mathrm{http}: / / w w w . o p e n m u s i c s c o r e . o r g /$

${ }^{20}$ http://www.gutenberg.org/wiki/Gutenberg:The Sheet_Music_Project

${ }^{21}$ Felhö alapú számítástechnika. 2015. 04. 21-i megtekintés, Wikipedia, http://hu.wikipedia.org/wiki/ Felh\%C5\%91_alap $\%$ C3\%BA_sz $\%$ C3\%A1m\%C3$\% \mathrm{ADt} \% \mathrm{C} 3 \% \overline{\mathrm{A}} 1$ stechnika

22 „Hallgatja” a játékost és követi. 